\title{
THE PROPOSAL FOR MONITORING OF STOAT MUSTELA ERMINEA (LINNAEUS, 1758) ON THE EXAMPLE OF POLAND
}

Faculty of Animal Breeding, Bioengineering and Conservation, Warsaw University of Life Sciences SGGW, Poland

\begin{abstract}
The ability to monitor species distribution and abundance is essential to detect changes in animal population and implement conservation management programs which can prevent further deterioration of the species' situation and help assess the progress of these programs. The stoat (Mustela erminea) is a small, extremely difficult to catch, predatory mammal which is under partial species protection in Poland. However, at the moment there are no deliberate actions conducted to protect it, and the strategy for the stoat monitoring has not been developed yet. This is directly related to various components, among which is the difficulty to develop an effective non-invasive method for capturing and identifying a stoat individual. The current state of knowledge regarding the distribution and abundance of the species in Poland is largely based on the observations reported to the coordinator, references in the literature, and photographs available on the Internet. The data, however, has not been confirmed by reliable field studies aimed to assess the current situation of this predator in Poland. This clearly indicates the need to deepen the knowledge about the distribution and abundance of the stoat in this country by starting the monitoring of the species. In this article, the first attempt was made to define the methodology needed to conduct it, which may be the base for further modification and refinement as new data is collected. A detailed description of the adopted methodology has been developed on the basis of methods successfully used in research on mustelids in other countries.
\end{abstract}

Key words: monitoring, stoat, Mustela erminea, Mustelidae.

\section{LEGAL STATUS AND THREAT OF SPECIES}

In terms of international law stoat (Mustela erminea) is included in Appendix III of the Bern Convention and in Appendix III of the Washington Convention (CITES). At the same time, the Indian subspecies Mustela erminea ferghanae is listed in Annex D of the Council Regulation of the European Community. In Poland, it is subject to partial species protection. In the IUCN red list, it has been categorized as LC - Least Concern (Reid et al. 2016).

\section{SPECIES DESCRIPTION}

The stoat is a small predatory mammal, one of the representatives of the Mustelidae family, slightly larger than the weasel (Mustela nivalis). Its body weight ranges from 150 to $450 \mathrm{~g}$, males may be heavier and longer than females. The body of a stoat is 22 to $29 \mathrm{~cm}$ long, while the tail is 11 to $15 \mathrm{~cm}$ long. The length of the hind foot is 4 to $5 \mathrm{~cm}$, and the ear length

Corresponding author: Alicja Podgrudna, Faculty of Animal Breeding, Bioengineering and Conservation, Warsaw University of Life Sciences - SGGW, Józefa Ciszewskiego 8, 02-786 Warszawa, Poland, e-mail: alicja.podgrudna@onet.pl 
is 1.5 to $2.5 \mathrm{~cm}$ (Serafiński 1965). This predator is characterized by a very slender and elongated body with short limbs. A long, slender neck supports a relatively small, triangular head with short, round ears, and small, dark eyes. The color of the stoat changes over the course of the year. During spring and summer it is brown except a clearly marked white belly. It turns fully white for winter which makes it possible to hide against the snow. A characteristic feature of the species is the black tip of the tail which does not change with the rest of the hair.

Among the Polish fauna only the weasel (Mustela nivalis) is distinctly similar to stoats in terms of morphology and ecology, having similar colors in spring and summer. During winter, the hair of a weasel turns either completely white, partially white, or remains brown (Serafiński 1965). The feature that clearly distinguishes a weasel from a stoat is a shorter, uniform in color tail. Weasels are also smaller and lighter than stoats. Other stoat-like species of the genus weasel (Mustela) that occur in Poland are: the American vison (Mustela vison), the steppe ferret (Mustela eversmanii) and the common ferret (Mustela putorius). All of them, similar to a stoat, are characterized by a slender, long body. However, they are distinguished by significant differences in coloration as well as larger size and body weight.

Many subspecies of the stoat have been discerned, and their wide reach includes tundra, boreal forests and deciduous forests in Asia, Europe and North America. An unequivocal taxonomic classification has yet to be made (Kurose et al. 2005). The stoat was introduced in New Zealand in the 19th century, where it is currently considered an invasive species due to the significant decline in native bird species, including endemic (O'Donnell et al. 1996). In Poland, there is probably a subspecies Mustela erminea aestiva described in 1792 in Germany. The stoat can be found all over the country, but its number is small (Buchalczyk 1964).

\section{SPECIES BIOLOGY}

The stoat is active mainly at night but can also be found hunting during the day (Murphy and Dowding 1995). It leads a terrestrial lifestyle. Due to the relatively small size and supple torso, the stoat has no problem with crossing really small gaps (Buchalczyk 1964). This predator shows no preference for the place intended for the nest, so it is not possible to determine the characteristic features of its environment (Murphy and Dowding 1995). It does not dig burrows - nooks and crannies naturally created by tree roots and stones serve as them (Murphy and Dowding 1995), although it also uses rural buildings such as barns, stables, or sheds (Serafiński 1965), or nests in abandoned hollows and burrows dug by other animals. Hair, moss, dry leaves, and feathers are used to line its nests (Buchalczyk 1964). It usually uses many different burrows, and regularly revisits only a few (Murphy and Dowding 1995).

The stoat has a relatively short life of 5 to 7 years. Males reach sexual maturity in the first year of life (Serafiński 1965). For females this stage occurs already in the nest when they are still naked and helpless. During this time, they mate with mature males (McDonald and Harris 2002). Estrus takes place in February and March. After the pregnancy which lasts about 70 days, the female gives birth to 4 to 8 young (Buchalczyk 1964). In the case of the stoat, however, there is also additional estrus in the summer. As a result, the fertilized blastocysts undergo a period of delayed implantation lasting from 9 to 12 months. In this case, the female is fertilized in one year, and childbirth takes place in the next. There is only one litter a year (McDonald and Harris 2002). 
The stoat, thanks to its good eyesight and hearing, great flexibility, and excellent hunting skills, can kill prey larger than itself such as rabbits, hares, and fawns (Buchalczyk 1964). However, it mainly hunts small rodents such as mice, hamsters, and voles (Murphy and Dowding 1995). During winter, rodents are their main food (Serafiński 1965). However, its victims are also birds, frogs, reptiles, insects and snails. It also feeds on found eggs and berries (Buchalczyk 1964; Serafiński 1965). When there is an excess of food, it makes supplies in its nest. The stoat feces are in the form of small, dark cylinders $0.5 \mathrm{~cm}$ by $2.7 \mathrm{~cm}$ in size (Buchalczyk 1964). In Poland, the victims of the stoat often fall on the European water vole (Arvicola amphibius). This is directly related to the fact that in Poland this predator lives mostly in water-related environments.

The main enemies of the species are dogs, foxes, birds of prey (including the eagle owl), and other larger species of the Mustelidae family (Buchalczyk 1964).

The individual area of the stoat in different parts of the world shows great variability, ranging from just 2 ha to as much as 368 ha. It may increase when the number of small rodents decrease. Research conducted in New Zealand with the use of radio transmitters has shown that the minimum size of the home areas for females is approximately 70 ha and for males 90 ha. The acreage lengths were appropriately $1.3 \mathrm{~km}$ and $2.5 \mathrm{~km}$ on average (Murphy and Dowding 1995). In Sweden, stoats establish territories in the fall, excluding other individuals of the same sex from their borders. Young females usually settle close to their birthplace, remaining there for life, while young males stay close to their birthplace only until winter and set off in search of their own territory in spring (Erlinge 1977; Murphy and Dowding 1995).

\section{HATCHING REQUIREMENTS}

The stoat inhabits deciduous and mixed forests, thickets, and mid-field thickets (Serafiński 1965). It can also be found on the edges of forests and in old run-down parks (Buchalczyk 1964). The results of research conducted on stoat in New Zealand confirmed that this predator does not show habitat preferences, and equally uses forests, their outskirts, open areas, and the vicinity of roads entering their acreage (Murphy and Dowding 1995). In Poland, this predator lives mainly in environments close to the water, in river valleys, and in thickets.

One of the factors determining the presence of a species and population density is food abundance. The availability of prey is extremely important due to the need to meet the daily demand for meat which in the case of a stoat is about $65 \mathrm{~g}$ (Buchalczyk 1964). At the same time, it should be noted that the limiting factor in any species is its natural enemies. Due to the changing climate and the associated snow winters that are less and less frequent in Poland, this aspect in the case of a stoat is increasing in importance, because the predator in a white winter coat is exposed to danger.

\section{SPECIES LOCATION IN POLAND}

The stoat can be found all over the country, but its number is small (Buchalczyk 1964).

As of April 29, 2021, 457 sightings of the species across 388 squares have been reported. The exact location of the stoat sites, designated among others thanks to the reports, is shown in the Fig. 1 below. 


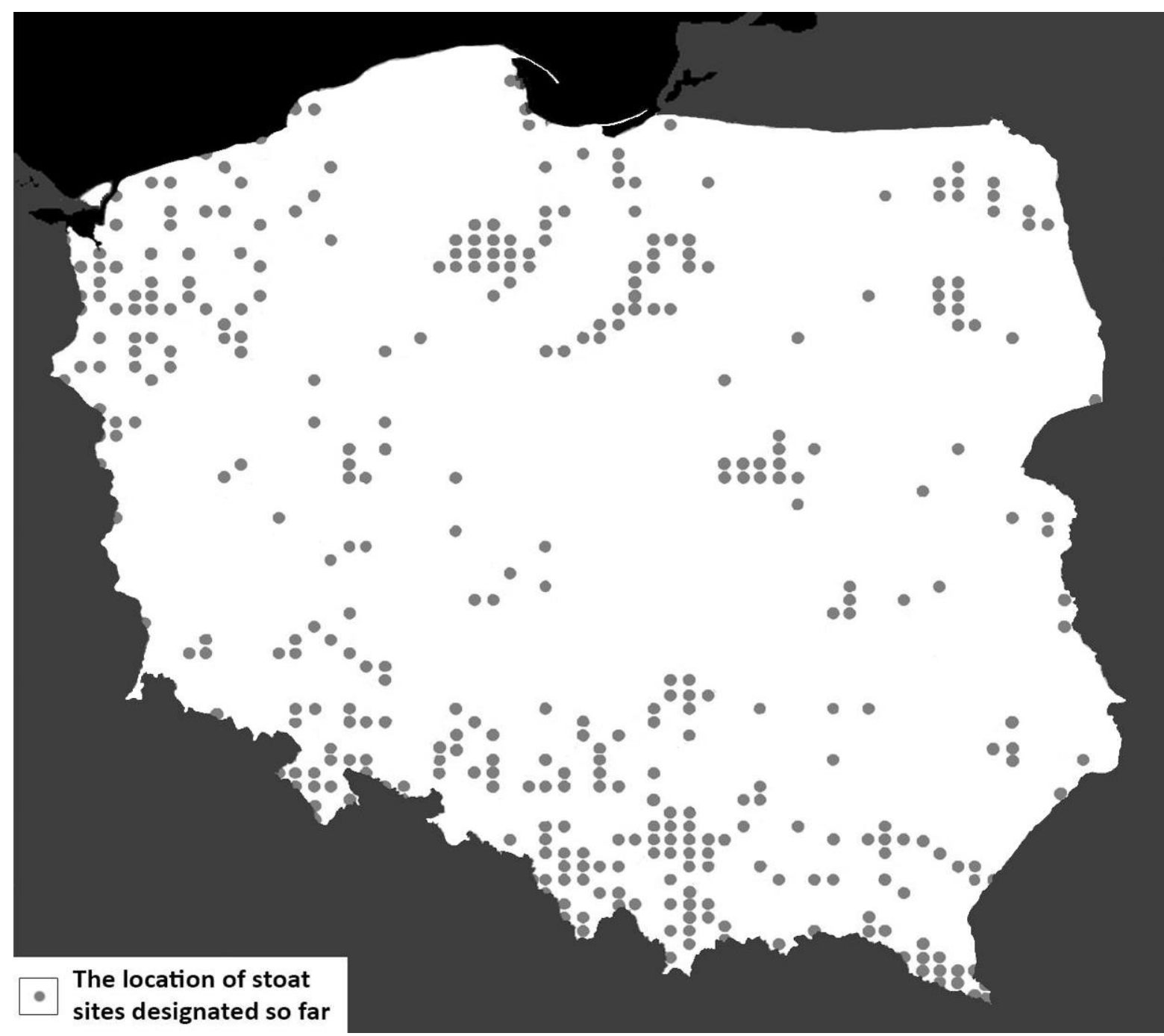

Fig. 1. Distribution of stoat sites in Poland (own development of a figure based on: Atlas ssaków Polski)

The stoat sites presented in Fig. 1 indicate that the highest density of the species occurs in the southern part of the country and in the Zachodniopomorskie Province. At the same time, many observations come from the Podlaskie Province, from the areas on west of Grudziądz, from the vicinity of Warsaw and from the area between Płock, Grudziądz, and Elbląg. In a large area of central Poland, the positions of the stoats are few and point-like.

Comprehensive research is necessary to verify that a species is present in locations where no observations have been reported. At the same time the state of the stoat population should be checked in the areas where the species has been observed so far. There is a risk that the predator no longer occurs in the indicated areas or is close to it. Population decline and disappearance may occur when immigration is limited, perhaps due to habitat degeneration (McDonald and Harris 2002).

\section{PURPOSE OF CREATING A MONITORING PROPOSAL}

The ability to monitor the distribution and abundance of species is essential to detect population changes and implement the necessary conservation management programs so that their progress can be assessed in the next step. Moreover, knowledge about the abundance 
of predators is highly important in the context of assessing the condition of the population of species that fall prey to them. Due to the lack of reliable methods of catching and monitoring the stoat, it is necessary to develop a methodology and verify its effectiveness, then introduce appropriate changes in order to increase its effectiveness. Considering the above and in the context of the poor knowledge of the distribution and abundance of the stoat in Poland, it was proposed to start monitoring in accordance with this study.

\section{SPECIES MONITORING CONCEPT}

The main assumption of the monitoring of the stoat is to assess the condition of its population and habitats in the areas designated for monitoring. Under the national law, the stoat is under partial species protection. For this reason, some of the methods that can be used for monitoring require the consent of the Regional Director of Environmental Protection. The proposed methodology of this monitoring was developed on the basis of methods successfully used in research on mustelids in other countries. The method described in the following chapters is non-invasive and does not take into account the trapping of individuals, so it does not require permits from the Local Ethics Committee for Animal Experiments and the Regional Director of Environmental Protection.

The stoat is a predator that prays on the European water vole (Arvicola amphibius), among others. Therefore, it prefers environments close to the water, in river valleys, and in thickets. For this reason, monitoring of the species should be started in the riverside areas, so that in the next step research will be carried out in the remaining areas where the stoat sites have been designated. Monitoring studies should be carried out in the long term, preferably in the perspective of several years, due to the fact that the number of the stoat may change significantly (high mortality of young, snowless winters). Taking into account the differences in the seasonal pattern of survival of male and female stoats (McDonald and Harris 2002), monitoring of the species with consideration of the seasons seems to be vital for ensuring comprehensiveness. In the longer term, field work should be expanded to areas where the species has not been observed so far.

The stoat is a small terrestrial mammal that has been researched using a variety of techniques. When assessing the stoat density in the Eglinton Valley in New Zealand, one of the factors used was the number of individuals killed by traps placed in fifty-six wooden tunnels spaced 100 meters apart. The second method used to assess the stoat density in the valley was based on the use of restrain traps (Murphy and Dowding 1995). Such traps are often selected when monitoring small terrestrial mammals. In the case of stoats, they were also used in Sweden to assess the distribution and dispersion of the population in relation to individuals of different sex, age, and social domination. Live-hunting traps are quite a good solution, but they have a number of limitations, especially in relation to predators: they require a lot of work, temporarily putting the caught individual to sleep, the use of live bait, and the consent of the Ethics Committee. Moreover, stoats are reluctant to enter traps, which makes them low-yielding in relation to this species.

Acquiring detailed information about the size of the individuals acreage or the movement of particular individuals enables radio tracking (Erlinge 1977). For stoat monitoring it is also possible to use booths with a camera built inside that records animals entering them. However, 
this method is relatively expensive and limited due to the inability to identify a specific individual. Another inexpensive method is the use of simple in the construction footprint-tracking tunnel (a pipe with a board on which there is a sponge soaked in a substance which causes the animals to leave traces). Snow tracking is also useful in case of stoats. However, both of these methods are burdened with difficulty due to the difficulty of distinguishing the tracks of male weasels from female stoats, caused by the overlapping sizes of their tracks (Mos and Hofmeester 2020). At the same time, due to the increasingly rarer snowy winters in Poland, the use of snow tracking begins to be a problem. Nevertheless, it is a good starting point that allows to observe the environments in which the stoat lives. This allows to locate the most appropriate places to set up photo-trap booths.

Research conducted in 2017 in New Zealand showed that the effectiveness of the methods used to detect stoats changes and it is depending on the season. In spring, artificial nests and photo-traps proved to be more efficient and profitable than footprint-tracking tunnels. However, the situation changed in the fall, when the footprint-tracking tunnels showed equal effectiveness in detecting the species (Smith and Weston 2017). In recent years a device called Mostela was created, which is a combination of a footprint-tracking tunnel and a camera trap. Due to its effectiveness compared to other methods used so far, it may become an innovative tool used to detect stoats in designated research areas. Mostela seems to be promising as a non-invasive monitoring method for confirming the presence and research on the ecology of small species belonging to the Mustelidae family. Further development of the tool would also allow the usage of Mostela to estimate the density of mustelids in the study area (Mos and Hofmeester 2020).

\section{INDICATORS AND ASSESSMENT OF THE CONSERVATION STATE OF THE SPECIES}

\section{Indicators of the state of the population}

The current state of knowledge regarding the distribution and abundance of species belonging to the Mustelidae family is unsatisfactory and indicates the need to deepen it. The stoat is poorly studied due to the difficulties of its detection and the lack of developed monitoring techniques (Mos and Hofmeester 2020). A variety of methods are still used in research on mustelids. At the same time, the sources contain the information mentioned previously in this study about the differences in the seasonal pattern of survival of male and female stoats. Moreover, the conducted research has shown that effectiveness of the methods used to detect the species changes depending on season.

Including the problems described above, the relative population size was selected as an appropriate indicator for assessing the state of the stoat population. It is an indicator which is easy to determine and allows to compare the results from different years and study areas in an uncomplicated way (Table 1).

Table 1. Indicator of the state of the stoat population

\begin{tabular}{lll}
\hline Indicator & \multicolumn{1}{c}{ Measure } & Way to determine/measure \\
\hline $\begin{array}{l}\text { Relative population } \\
\text { size }\end{array}$ & $\begin{array}{l}\text { Number of } \\
\text { individuals } \\
\text { observed }\end{array}$ & $\begin{array}{l}\text { The total number of individuals registered by camera traps located } \\
\text { in Mostelas deployed in the study area }\end{array}$ \\
\hline
\end{tabular}


The number of used Mostelas depends on the size of the studied area. For instance, in order to place the optimal number of devices in the selected area of 50 ha, 20 Mostelas should be placed at a distance of about 141.4 meters from each other. However, this would entail a high financial burden because the device equipped with a photo-trap remains relatively new and expensive. On the other hand, it is possible to place a smaller number of Mostelas, considering the greater distances between the places selected for them. It should be noted that this solution would involve their systematic transfer in order to cover the entire area under investigation. In such a case, the optimal area for study should be about 50 ha with 8 Mostelas situated in selected places in a distance of 150 meters from each other (Table 2).

Table 2. Valorization of the stoat population status indicator

\begin{tabular}{|c|c|c|c|}
\hline \multirow{2}{*}{ Indicator } & \multicolumn{3}{|c|}{ Rating } \\
\hline & FV & U1 & U2 \\
\hline $\begin{array}{l}\text { Relative } \\
\text { population } \\
\text { size }\end{array}$ & $\begin{array}{l}\text { More than a dozen individuals } \\
\text { observed in the selected } \\
\text { area during the study period }\end{array}$ & $\begin{array}{l}3-10 \text { individuals observed } \\
\text { in the selected area during } \\
\text { the study period }\end{array}$ & $\begin{array}{l}\text { No individuals or a single observation } \\
\text { were observed in the selected } \\
\text { area during the study period }\end{array}$ \\
\hline
\end{tabular}

FV - appropriate condition, U1 - unsatisfactory condition, U2 - inappropriate/bad condition.

\section{Assessment of the state of the population}

The assessment of the condition of the population corresponds to the assessment of the relative population size indicator.

\section{Indicators of the state of the habitat}

The presence of water reservoirs and the availability of prey were assumed as the habitat indicators which allow for the assessment of the preservation of the habitat of stoats. The valorization of habitat indicators is indicative and based, inter alia, on subjective judgment of experts.

Due to the habitat preferences of the stoats living in Poland, the presence of water reservoirs was selected as the first indicator determining the condition of the habitat. In Poland, this predator lives in areas close to the water, in river valleys, and in thickets. Taking this fact into account, it is important to determine whether there are water reservoirs in the studied area or in its immediate vicinity.

Food abundance is included in the factors which determine the presence of the species and the density of the population. The availability of potential prey is highly important because of necessity to fulfill the daily demand for meat. For this reason, it is a characteristic that should be included in the indicators of the state of the stoat habitat. Considering the fact that the biomass of the main groups which are part of the diet of the stoat is currently unknown in Poland, a substitute descriptive indicator which takes into account the measurement method possible to use while assessing the condition of the species habitat was proposed in the methodology. The availability of food in the habitat is subject to an alternative analysis which aims to determine the approximate species composition as well as whether there are small rodents and Leporidae in the study area. 
Appropriate habitats for the stoat are conditioned by obtaining the FV assessment defined as the proper condition (Table 3). The remaining assessments of the condition of habitats, i.e. U1 and U2, denoting successively unsatisfactory and bad condition, correspond to suboptimal and unsuitable habitats for the species (Table 4).

Table 3. Indicators of the state of the stoat habitat

\begin{tabular}{lll}
\hline Indicator & \multicolumn{1}{c}{ Measure } & \multicolumn{1}{c}{ Way to determine/measure } \\
\hline $\begin{array}{l}\text { The presence of } \\
\text { water reservoirs }\end{array}$ & $\begin{array}{l}\text { descriptive } \\
\text { indicator }\end{array}$ & $\begin{array}{l}\text { Determining whether there are water reservoirs in or around the study } \\
\text { area }\end{array}$ \\
\hline Availability of prey & $\begin{array}{l}\text { Confirmation of the presence/absence of small rodents and Leporidae } \\
\text { in the studied area and determination of the approximate species } \\
\text { composition based on field observations (expert assessment), } \\
\text { inderview with residents, data from studies conducted on these groups } \\
\text { in previous years and data from pellets }\end{array}$ \\
\hline
\end{tabular}

Table 4. Valorization of the stoat habitat status indicators

\begin{tabular}{|c|c|c|c|}
\hline \multirow{2}{*}{ Indicator } & \multicolumn{3}{|c|}{ Rating } \\
\hline & FV & U1 & U2 \\
\hline $\begin{array}{l}\text { The presence } \\
\text { of water } \\
\text { reservoirs }\end{array}$ & $\begin{array}{l}\text { Presence of water reservoirs } \\
\text { in the study area and possibly } \\
\text { within } 250 \text { meters of it }\end{array}$ & $\begin{array}{l}\text { There are no water reservoirs } \\
\text { in the study area, but they are } \\
\text { present within } 250 \text { meters of it }\end{array}$ & $\begin{array}{l}\text { There are no water } \\
\text { reservoirs in the study area } \\
\text { and within } 250 \text { meters of it }\end{array}$ \\
\hline $\begin{array}{l}\text { Availability of } \\
\text { prey }\end{array}$ & $\begin{array}{l}\text { Significant species diversity } \\
(>4) \text { and the number of } \\
\text { species belonging to small } \\
\text { rodents and Leporidae in the } \\
\text { study area }\end{array}$ & $\begin{array}{l}\text { Average species diversity (3-4) } \\
\text { and number of species } \\
\text { belonging to small rodents and } \\
\text { Leporidae in the study area }\end{array}$ & $\begin{array}{l}\text { Little species diversity }(<3 \\
\text { species) and the number of } \\
\text { species belonging to small } \\
\text { rodents and Leporidae in } \\
\text { the study area }\end{array}$ \\
\hline
\end{tabular}

FV - appropriate condition, U1 - unsatisfactory condition, U2 - inappropriate/bad condition

\section{Assessment of the state of the habitat}

The assessment of the condition of the habitat in the studied area is determined by the lower of the two indicators.

\section{Protection perspectives}

The parameter concerning the protection prospects is an expert assessment which considers the current state of the population and habitat in the study area in perspective of the next few years. Therefore, the assessment of the perspectives should take into account the relative population size and environmental conditions. At the same time, it is important to observe and predict threats and negative impact which include the decline in the abundance of the food base, climate warming, or falling prey to larger predators. They can lead to the deterioration of the population's condition or its disappearance. Protection perspectives are assessed similarly to the previous parameters on a three-point scale:

- FV - appropriate condition (fine perspectives); data of the relative population size, favorable habitat conditions, and the lack of significant threats indicate that the population will develop or remain at the same level in the perspective of coming years; 
- U1 - unsatisfactory condition (not favorable perspectives); deterioration of the populations condition and/or habitat is probable, or it is suspected that the current unsatisfactory condition will continue;

- U2 - inappropriate condition (bad perspectives); the condition of the population and/or habitat is bad, it will deteriorate for instance due to the emergence of new threats, or there is a suspicion that the current bad condition will continue.

\section{Overall assessment}

The overall rating considers the assessment of all the parameters described above (population, habitat, protection perspectives). The general assessment corresponds to the lowest rating of these parameters.

\section{DESCRIPTION OF MONITORING STUDIES - THE CHOICE OF MONITORING AREAS AND THEIR SUGGESTED SIZE}

The monitoring area in the stoat's case is a well-defined and clearly delineated acreage where the field work is carried out. The area does not have to be protected. However, it is important that it initially coincides with the observations of the species recorded so far and takes into account its habitat preferences.

The most important goal of monitoring studies is to confirm the presence of the stoat in the selected area, and to determine the relative population size. The adopted method is based on counting individuals recorded by photo-traps located in Mostelas (catching is always stressful for animals and it would require obtaining permits from the Local Ethical Committee for Animal Experiments and the Regional Director of Environmental Protection). The use of Mostelas allows for a reliable and effective verification of the species presence in the entire monitored area.

The number of used Mostelas depends on the size of the studied area. The optimal monitoring area presented in this article is a square of approximately 50 ha in size, designated in the area where the species was previously observed. 8 Mostelas should be placed at the monitored area in the distance of 150 meters apart from each other. The devices should be systematically moved in order to cover the entire area by research works.

\section{METHOD OF PERFORMING RESEARCH - INVESTIGATION OF THE STATE OF THE POPULATION INDICATOR}

A number of studies of the stoat have been carried out using a variety of techniques, such as live-hunting traps, footprint-tracking tunnels, artificial nests, photo-traps, snow tracking, and radio tracking. At the same time, the research showed that the effectiveness of the methods used to detect the species changes depending on the season. In recent years, as mentioned previously, Mostela was created, which is characterized by a greater efficiency compared to the other methods used so far. The tool seems to be a promising non-invasive monitoring method which may have a great importance in the future for confirming the presence and research on the ecology of small species belonging to the Mustelidae family. 
Considering the above, the proposed methodology of stoat monitoring is based on counting individuals recorded by photo-traps located in Mostelas, which were designed to register small mustelids. From the outside the device looks like a small wooden box made of $12 \mathrm{~mm}$ thick shuttering plywood. It combines a photo-trap with a footprint-tracking tunnel, which in the case of Mostela is a transparent PVC drainpipe with a diameter of $10 \mathrm{~cm}$. The combination of the two methods, previously used separately, greatly increases the simultaneous probability of detecting stoats, with the possibility of identifying a specific individual. The photo-trap should be set to record 30-second videos after it is triggered. Then there should be an approximately 1-minute delay before it will be possible to restart the photo-trap. In order to obtain a sharper image of animals, an additional lens in form of a set of plastic reading glasses can be placed in front of the photo-trap (Mos and Hofmeester 2020). This will increase the sharpness by a few diopters.

The devices should be hidden in natural landscape elements which are corridors that can be used by stoats to move to other places. In order to increase the effectiveness of monitoring, it is recommended to leave the Leporidae smell inside the tunnel located in the Mostela. Devices should be moved every two weeks. At the same time, the photo-traps should be operated by replacing the batteries and memory cards which are located in them. The records of any animal made by the camera trap require species determination. For each identified individual of the stoat, an attempt to determine the size, sex, and approximate age (juvenile, adult) should be made.

\section{METHOD OF PERFORMING RESEARCH - INVESTIGATION OF THE STATE OF THE HABITAT INDICATOR}

Determining the boundaries of the area on which the species may appear should begin with finding the central point corresponding to the site included in the Atlas ssaków Polski and marking it with a stake. Then, with the help of measures, an area subjected to field works should be designated, for instance a square of approximately 50 ha in size (the side length in this case is 707 meters). The vertices of the square should be marked with stakes. Their location in the field should be marked on a map (preferably on a scale of 1:10 000) which outlines the boundaries of the monitored area.

The presence of water reservoirs. The indicator is assessed on the basis of the presence/ /absence of water reservoirs in the appointed area or at the distance of 250 meters from it.

Availability of prey. The indicator is assessed on the basis of the presence/absence of small rodents and Leporidae in the appointed area. At the same time, the approximate species composition should be determined on the basis of field observations (expert assessment), an interview with inhabitants, data from research conducted on the above-mentioned groups in previous years, and data from pellets.

\section{DATE AND FREQUENCY OF RESEARCH}

The stoat is an active species all year round, but its greatest abundance can be found in summer and autumn when individuals born in spring begin to appear in the field. At the same time, it is the most optimal term for people carrying out field work, due to more favorable 
weather conditions. Nevertheless, while choosing the date it is very important to take into account the effectiveness of the selected method which allows for the detection of the species in relation to the season during which monitoring is planned.

The decision to use Mostelas means that the study of the state of population and the state of the habitat should be carried out from mid-June to mid-November. Initially, they should be held annually in order to evaluate the determined indicators. The frequency can be extended, and the research can be carried out at intervals of several years, provided that there have been at least 3 monitoring works, and the stability and lack of threats to the stoat population has been confirmed.

\section{EQUIPMENT AND MATERIALS FOR RESEARCH}

In order to conduct the research, it is necessary to use specific equipment and materials. The following will be necessary for this purpose: an orthophotomap, a GPS device (to accurately assess the geographic location of the study area), a compass (useful when determining the area), a detailed topographic map (scale 1:10 000), a pencil, a pen or a marker (to mark points on the map), metal measuring tapes (50 and $100 \mathrm{~m}$ ), stakes (for marking the vertices of the determined area and the central point), a camera (for documentation of the study area), Mostelas (optimal 8 per 50 ha), durable batteries for photo-traps, large memory cards for photo-traps, a desktop computer or a laptop (for saving materials from phototraps with the possibility of their playback), access to the Microsoft Office package (the ability to easily save data about observed animals and later analysis), keys for marking mammals (e.g. Pucek 1984), a backpack or an off-road bag, an off-road car with a spacious trunk, optionally parts of a rabbit or a hare in order to leave the smell in the Mostelas.

\section{GENETIC MONITORING}

Genetic monitoring appears to be a relevant factor in research, and has been constantly growing in importance over the years. It provides a great deal of valuable information regarding sex ratio, individual movement, and interconnection between populations. In addition, microsatellite markers are useful tools for assessing genetic variation within and between populations (Fleming et al. 1999). Thanks to genetic monitoring, we are also able to know the degree of relationship between different populations. At the same time, it should be remembered that genetic monitoring is limited by high costs and possible problems related to DNA analysis. Nevertheless, thanks to the information obtained, we are able to confirm the observation of a specific individual, which makes it possible to estimate the minimum number of individuals in the selected area. For this reason, it seems necessary to add genetic monitoring as a component of the monitoring of the stoat population.

First of all, designing of the genetic monitoring should start with determining the biological material which will be used for later analysis. The basic assumption of the described monitoring proposal is the lack of direct contact between the researcher and the animal. For this reason it is not possible to collect some analytical materials from stoats, such as blood. At the same time, it is necessary to take into consideration the time of year during which the material will 
be collected, and the possibilities offered by the introduced tool which will be used during monitoring researches. Work on mustelids in North America has helped to identify enough loci in the genome of the stoat to allow individual identification. Sufficient DNA for analysis has been obtained from samples of skin, hair and feces (Jones et al. 2004). Taking into account the research carried out in the summer and autumn with the use of Mostelas, hair was selected as the biological material collected from stoat in this study. At the same time, we must remember that hair shaft does not contain DNA. Thus, hair samples must be removed with the root or follicle intact (Jones et al. 2004). The material will be collected using a metal spring stretched across the mouth of a Mostela. It is a system which has been used to collect hair samples from pine martens (Martes martes) in Britain (Jones et al. 2004). The biological material collected in this way from stoats will be gathered each time during the inspections of Mostelas which included, inter alia, replacing batteries and memory cards from photo-traps. The hair should be protected in previously prepared envelopes and stored in a dry place until the analyses are carried out.

Species identification can be accomplished by carrying out amplification of a region of the mitochondrial gene cytochrome $b$ by polymerase chain reaction. The presence of mustelids DNA can be additionally tested by amplification of a segment of cytochrome $b$, using the mustelid-specific primer set Mustcytb L and Mustcytb H (Prada et al. 2014). During the laboratory analysis process, it is important to properly perform DNA extraction, amplification ,and sequencing. All samples can be successfully genotyped using selected microsatellite loci developed from various mustelids species (McMurtrie et al. 2011). The primers used may be, for example, MER005, MER009, MER022, MER030 and MER041 developed from Mustela erminea (Fleming et al. 1999; Gleeson et al. 2010; McMurtrie et al. 2011) and MVIS072 (Fleming et al. 1999) or MVI057 (Gleeson et al. 2010; McMurtrie et al. 2011) developed from Mustela vison. Genotypic profiles can be analysed visually and using software such as Genotyper (Gleeson et al. 2010). After laboratory analyses, there should be performed statistical analyses. Then the obtained results must be interpreted and a report should be prepared.

\section{CONCLUSIONS}

The current state of knowledge regarding the distribution of the species in Poland is largely based on the observations reported to the coordinator. Nevertheless, a significant part of the sites was appointed on the basis of references in the literature and the identification of the species on the basis of photographs available on the Internet. With the current knowledge of the distribution and abundance of the species, not confirmed by reliable field studies, it is not yet possible to develop an ideal methodology for stoat monitoring. The current proposal is the first attempt to define it. The methodology will be refined, as new data will be collected.

The stoat is a species that remains extremely difficult to capture. Research conducted in various countries often did not bring the intended results, despite the use of various techniques, such as live-hunting traps, footprint-tracking tunnels, artificial nests or photo-traps, 
as well as radio tracking and snow tracking. This is directly related to the fact that each of these was associated with imperfections or limitations, such as the reluctant entry of stoats into live-hunting traps. On the other hand, the use of only footprint-tracking tunnels or snow tracking is burdened with, inter alia, the possibility of making a mistake because of difficulties in distinguishing the tracks of male weasels and female stoats due to the overlapping size of their tracks. At the same time, research conducted in 2017 in New Zealand showed that the effectiveness of the methods used to detect stoats changes depending on the season. Mostela turned out to be an effective tool used in 2017-2018 for research on weasels in the United Kingdom. Due to its effectiveness compared to other methods used so far, it may become an innovative tool used to detect stoats in designated research areas. Expanding it with genetic monitoring could further help to identify specific individuals and estimate the population density. A detailed description of the adopted methodology for monitoring the stoat population in Poland, based on the selected method using Mostela, is presented in the section on the description of monitoring studies.

The stoat is under partial species protection in Poland, however, there are no activities to protect it at the moment. The ability to monitor the distribution and abundance of species is essential to detect population changes and implement the necessary conservation management programs so that their progress can be assessed in the next step. The current state of knowledge regarding the distribution and abundance of the species indicates the need to deepen it by starting the monitoring at the sites designated so far. In the future, a search for stoats should be carried out in potential places of their occurrences throughout Poland. Determined sites, after updating the prepared development, should be included in the species monitoring.

The monitoring methodology proposed in this article was developed on the basis of methods successfully used in research on mustelids in other countries. Therefore, it can be successfully applied to other species belonging to the Mustelidae family, as they have similar ecological requirements.

\section{ACKNOWLEDGEMENTS}

I would like to sincerely thank Professor Joanna Gruszczyńska for sharing her knowledge and introducing the subject of animal monitoring to me. In addition, I would like to thank my loved ones for their invaluable support, understanding, and patience during the creation of the stoat monitoring project.

\section{REFERENCES}

Buchalczyk T. 1964. Drapieżne - Carnivora, in: Klucze do oznaczania kręgowców Polski, cz. V. Ssaki - Mammalia, ed. K. Kowalski. Warszawa, Państwowe Wydawnictwo Naukowe, 215-217, 220-222. [in Polish]

Erlinge S. 1977. Spacing strategy in stoat Mustela erminea. OIKOS. 28, 32-42. 
Fleming M.A., Ostrander E.A., Cook J.A. 1999. Microsatellite markers for American mink (Mustela vison) and ermine (Mustela erminea). Mol. Ecol. 8, 1352-1354.

Gleeson D.M., Byrom A.E., Howitt R.L. 2010. Non-invasive methods for genotyping of stoats (Mustela erminea) in New Zealand: potential for field applications. N. Z. J. Ecol. 34(3), 356-359.

Instytut Ochrony Przyrody PAN, 2010. Atlas ssaków Polski, https://www.iop.krakow.pl/Ssaki/ /gatunek/111, access: 30.05.2021.

Jones C., Moller H., Hamilton W. 2004. A review of potential techniques for identifying individual stoats (Mustela erminea) visiting control or monitoring stations. N. Z. J. Zool. 31, 193-203.

Konwencja o międzynarodowym handlu dzikimi zwierzętami i roślinami gatunków zagrożonych wyginięciem sporządzona w Waszyngtonie dnia 3 marca 1973 r. DzU z 4 kwietnia 1991 r., nr 27, poz. 112. [in Polish]

Konwencja o ochronie gatunków dzikiej flory i fauny europejskiej oraz ich siedlisk, sporządzona w Bernie dnia 19 września 1979 r. DzU z 25 maja 1996 r., nr 58, poz. 263. [in Polish]

Kurose N., Abramov A.V., Masuda R. 2005. Comparative phylogeography between the ermine Mustela erminea and the least weasel $M$. nivalis of Palaearctic and Nearctic regions, based on analysis of mitochondrial DNA control region sequences. Zool. Sci. 22(10), 1069-1078.

McDonald R.A., Harris S. 2002. Population biology of stoats Mustela erminea and weasels Mustela nivalis on game estates in Great Britain. J. Appl. Ecol. 39, 793-794.

McMurtrie P., Edge K-A., Crouchley D., Gleeson D., Willans M.J., Veale A.J. 2011. Eradication of stoats (Mustela erminea) from Secretary Island, New Zealand, in: Island invasives: eradication and management. IUCN, Gland, Switzerland, 455-460.

Mos J., Hofmeester T.R. 2020. The Mostela: an adjusted camera trapping device as a promising non-invasive tool to study and monitor small mustelids. Mammal Res. 65(4), 843-853.

Murphy E.C., Dowding J.E. 1995. Ecology of the stoat in Nothofagus forest: Home range, habitat use and diet at different stages of the beech mast cycle. N. Z. J. Ecol. 19(2), 97-109.

O'Donnell C.F., Dilks P.J., Elliott G.P. 1996. Control of a stoat (Mustela erminea) population irruption to enhance mohua (yellowhead) (Mohoua ochrocephala) breeding success in New Zealand. N. Z. J. Zool. 23(3), 279-286.

Prada D., Veale A., Duckworth J., Murphy E., Treadgold S., Howitt R., Hunter S., Gleeson D.M. 2014. Unwelcome visitors: employing forensic methodologies to inform the stoat (Mustela erminea) incursion response plan on Kapiti Island. N. Z. J. Zool. 41(1), 1-9.

Pucek Z. 1984. Klucz do oznaczania ssaków Polski. Warszawa, PWN. [in Polish]

Reid F., Helgen K., Kranz A. 2016. Mustela erminea. The IUCN red list of threatened species 2016, https://www.iucnredlist.org/fr/species/29674/45203335, access: 04.08.2021.

Rozporządzenie Ministra Środowiska z dnia 16 grudnia 2016 r. w sprawie ochrony gatunkowej zwierząt. DzU z 28 grudnia 2016 r., poz. 2183. [in Polish]

Rozporządzenie Rady (WE) NR 338/97 z dnia 9 grudnia 1996 r. w sprawie ochrony gatunków dzikiej fauny $\mathbf{i}$ flory $\mathbf{w}$ drodze regulacji handlu nimi. Dziennik Urzędowy Unii Europejskiej z 3 marca 1997 r., 061, 0001-0069. [in Polish]

Serafiński W. 1965. Ssaki Polski. Atlas. Warszawa, Wydawnictwo Szkolne i Pedagogiczne, 50-51. [in Polish]

Smith D.H., Weston K.A. 2017. Capturing the cryptic: a comparison of detection methods for stoats (Mustela erminea) in alpine habitats. Wildl. Res. 44(5), 418-426.

\section{PROPOZYCJA MONITORINGU GRONOSTAJA MUSTELA ERMINEA (LINNAEUS, 1758) NA PRZYKŁADZIE POLSKI}

Streszczenie. Możliwość monitorowania rozmieszczenia i liczebności gatunków jest niezbędna do wykrywania zmian zachodzących wśród populacji zwierząt oraz wdrożenia w odpowiednim momencie programów zarządzania ochroną, co może pozwolić zapobiec dalszemu pogarszaniu 
się sytuacji danego gatunku i pomóc w ocenie postępów wprowadzonych programów ochronnych. Gronostaj (Mustela erminea) to niewielki, niezwykle trudny do uchwycenia ssak drapieżny, który jest objęty w Polsce częściową ochroną gatunkową. Obecnie nie są jednak prowadzone żadne celowe działania na rzecz jego ochrony, a także nie został dotychczas opracowany jego monitoring. Jest to bezpośrednio powiązane z różnymi składowymi, między innymi trudnością w wypracowaniu skutecznej nieinwazyjnej metody pozwalającej na uchwycenie i zidentyfikowanie osobnika. Obecny stan wiedzy odnośnie do rozmieszczenia i liczebności gatunku w Polsce w dużej mierze opiera się na zgłoszonych do koordynatora obserwacjach, wzmiankach w literaturze oraz udostępnionych w Internecie fotografiach. Dane jednak nie zostały potwierdzone rzetelnymi badaniami terenowymi mającymi na celu zorientowanie się, jak wygląda aktualnie sytuacja tego drapieżnika w Polsce. Wskazuje to jednoznacznie na konieczność pogłębienia wiedzy dotyczącej rozmieszczenia i liczebności gronostaja w tym kraju poprzez rozpoczęcie monitoringu gatunku. W niniejszym artykule podjęta została pierwsza próba określenia metodyki potrzebnej do jego prowadzenia, która może stanowić podstawę do dalszej modyfikacji i dopracowywania w miarę gromadzenia nowych danych. Dokładny opis przyjętej metodyki monitoringu populacji gronostaja w Polsce opracowano, opierając się na metodach skutecznie wykorzystanych do badań nad łasicowatymi w innych krajach.

Słowa kluczowe: monitoring populacji, Mustela erminea, łasicowate. 
